\title{
Neuropeptide Y suppresses epileptiform discharges by regulating AMPA receptor GluR2 subunit in rat hippocampal neurons
}

\author{
WEI BU ${ }^{1}$, WEN-QING ZHAO ${ }^{2,3}$, WEN-LING LI ${ }^{3}$, CHANG-ZHENG DONG $^{3}$, ZHE ZHANG $^{3}$ and QI-JUN LI ${ }^{4}$ \\ ${ }^{1}$ Department of Neurosurgery, The Third Hospital of Hebei Medical University, Shijiazhuang, Hebei 050051; \\ ${ }^{2}$ Department of Neurosurgery, Hebei Medical University; ${ }^{3}$ Department of Functional Neurosurgery, \\ Hebei General Hospital, Shijiazhuang, Hebei 050051; ${ }^{4}$ Department of Orthopaedics, \\ Shijiazhuang Third Hospital, Shijiazhuang, Hebei 050017, P.R. China
}

Received February 16, 2016; Accepted February 9, 2017

DOI: $10.3892 / \mathrm{mmr} .2017 .6567$

\begin{abstract}
The present study aimed to investigate the effects of neuropeptide Y (NPY) on the $\alpha$-amino-3-hydroxy-5-methyl-4isoxazolepropionic acid (AMPA) receptor glutamate receptor 2 (GluR2) subunit in epileptiform discharge hippocampal neurons. Hippocampal neurons were harvested from neonatal Sprague-Dawley rats aged $<24 \mathrm{~h}$ and primarily cultured in vitro. At day 12 following culture, hippocampal neurons were divided into the following groups: Control, $\mathrm{Mg}^{2+}$-free, $\mathrm{NPY}+\mathrm{Mg}^{2+}$-free and BIBP3226+NPY+Mg ${ }^{2+}$-free. The action potential of neurons was measured using the whole cell patch clamp technique in the control, $\mathrm{Mg}^{2+}$-free and $\mathrm{NPY}+\mathrm{Mg}^{2+}$-free groups. AMPA current $\left(\mathrm{I}_{\mathrm{AMPA}}\right)$ was detected and peak current density was calculated in each group. Alterations in total protein and phosphorylation of the GluR2 subunit were detected by western blot analysis, and GluR2 mRNA expression levels were detected by reverse transcription-quantitative polymerase chain reaction, in each group. The whole cell patch clamp technique demonstrated an abnormal action potential in the $\mathrm{Mg}^{2+}$-free group. The frequency and amplitude of the action potential were significantly greater in the $\mathrm{Mg}^{2+}$-free group compared with the control group, and significantly reduced in the NPY $+\mathrm{Mg}^{2+}$-free group compared with the $\mathrm{Mg}^{2+}$-free group $(\mathrm{P}<0.05)$. In the $\mathrm{Mg}^{2+}$-free group, compared with the control group, peak current density was significantly reduced $(\mathrm{P}<0.05)$, GluR2 subunit protein content was slightly reduced $(\mathrm{P}>0.05)$, phosphorylation levels of GluR2 subunit were significantly greater $(\mathrm{P}<0.05)$ and GluR2 mRNA was significantly reduced $(\mathrm{P}<0.05)$. In the $\mathrm{NPY}+\mathrm{Mg}^{2+}$-free group, compared with the $\mathrm{Mg}^{2+}$-free group, peak current density was significantly greater $(\mathrm{P}<0.05)$, phosphorylation levels of GluR2 subunit were significantly reduced $(\mathrm{P}<0.05)$ and
\end{abstract}

Correspondence to: Dr Wen-Qing Zhao, Department of Neurosurgery, Hebei Medical University, 361 Zhongshan East Road, Shijiazhuang, Hebei 050051, P.R. China

E-mail: wenqingzhaohebei@sina.com

Key words: hippocampus, neurons, primary culture, epilepsy, patch clamp, $\alpha$-amino-3-hydroxy-5-methyl-4-isoxazolepropionic acid current, glutamate receptor 2 subunit, neuropeptide $\mathrm{Y}$
GluR2 mRNA expression was significantly greater $(\mathrm{P}<0.05)$. In the BIBP3226+NPY+ $\mathrm{Mg}^{2+}$-free group, compared with the $\mathrm{NPY}+\mathrm{Mg}^{2+}$-free group, peak current density was significantly reduced $(\mathrm{P}<0.05)$, phosphorylation levels of GluR2 subunit were significantly greater $(\mathrm{P}<0.05)$ and GluR2 mRNA expression was significantly reduced $(\mathrm{P}<0.05)$. After $3 \mathrm{~h}$ of treatment with $\mathrm{Mg}^{2+}$-free extracellular fluid, epileptiform discharge was detected in the cells. NPY inhibited the discharge and its underlying mechanism may be that epileptiform discharge suppressed the function of the AMPA receptor GluR2 subunit. NPY relieved the inhibition of the GluR2 subunit via the Y1 receptor. This may provide a novel direction for future studies on the pathogenesis and treatment of epilepsy.

\section{Introduction}

Epilepsy is a common clinical disease characterized by abnormal discharge from neurons in the brain. The pathogenesis of epilepsy remains to be fully elucidated and its causes are complex. The hippocampus is the site of high concentration of neurons and has an important role in the pathogenesis of epilepsy (1). Excitatory and inhibitory neurotransmitters present in the central nervous system maintain normal cerebral function, and glutamate is an important excitatory neurotransmitter in the brain. Glutamate receptor (GluR) dysfunction may be an important cause of epilepsy (2). Excessive activation of GluRs may cause neuronal damage, a variety of neurological damage, and chronic neurodegenerative diseases (3). The $\alpha$-am-ino-3-hy droxy-5-methyl-4-isoxazolepropionic acid (AMPA) receptor is an important subtype of ionotropic GluRs (4) and is composed of four subunits (GluR1, 2, 3 and 4). The primary features of AMPA receptors are determined by GluR2, with GluR2 protein downregulation considered to be a molecular switch. Blocking or reducing GluR2 expression forms a calcium-permeable AMPA receptor, which increases $\mathrm{Ca}^{2+}$ influx and enhances endogenous glutamate excitotoxicity (5). In the central nervous system, the GluR2 subunit is highly expressed in various neurons. Under normal conditions, GluR2 is abundant in synapses. Following hypoxia, the expression of GluR2 on the surface of the neuron membrane is significantly decreased, indicating that the mechanism of blocking $\mathrm{Ca}^{2+}$ influx has weakened. Without a GluR2 subunit, the $\mathrm{Ca}^{2+}$ permeability of 
AMPA receptors increases and a large $\mathrm{Ca}^{2+}$ influx is detected, which may activate a series of intracellular protein kinases or immediate early genes. The decreased GluR2 expression induced by epileptic seizure causes an increase in the $\mathrm{Ca}^{2+}$ permeability of AMPA receptors, resulting in $\mathrm{Ca}^{2+}$ overload, which is an important cause of delayed neuronal death in hippocampal neurons (6). Neuropeptide Y (NPY) contains 36 amino acids and was first extracted from the brain tissue of pigs by Tatemoto et al (7) in 1982. It is widely distributed in the central and peripheral nervous systems (8). In the central nervous system, NPY concentrations are greatest in the hippocampus. NPY has a protective effect on cerebellum neuronal cells cultured in vitro and has been demonstrated to possess an anti-epileptic effect (9); however, its protective effects are weakened following blocking of NPY Y1 and Y2 receptors, suggesting that NPY exerts neuroprotective effects via these receptors (10). The present study aimed to investigate the functional alterations in the GluR2 subunit induced by epileptiform discharge in hippocampal neurons and to investigate whether NPY affects these functional alterations.

\section{Materials and methods}

Animals and reagents. A total of 64 clean male Sprague-Dawley rats, which were born within $24 \mathrm{~h}$ were provided by the Experimental Animal Center of Hebei Medical University (animal license no. SCXK (Ji) 2013-1-003; Shijiazhuang, China). The rats were maintained in a $12 \mathrm{~h}$ light/dark cycle, humidity of $60 \pm 5 \%, 22 \pm 3^{\circ} \mathrm{C}$. All rats were allowed free access to food and water. All animal experimental procedures were performed in strict accordance with the Guidance Suggestions for the Care and Use of Laboratory Animals of National Institutes of Health (U.S.) and the protocol was approved by the Institutional Animal Care Committee of Hebei Medical University. Neurobasal medium, B-27, L-glutamine, fetal bovine serum (FBS; special grade) and Dulbecco's modified Eagle's medium (DMEM)/F-12 medium were purchased from Gibco; Thermo Fisher Scientific, Inc. (Waltham, MA, USA); poly-L-lysine and trypsin from Sigma-Aldrich; Merck KGaA (Darmstadt, Germany); and AMPA, NPY and BIBP3226 from Enzo Life Sciences, Inc. (Farmingdale, NY, USA).

Rabbit anti-microtubule-associated protein 2 (MAP-2) (cat. no. 17490-1-AP) polyclonal antibody and fluorescein isothiocyanate(FITC)-labeled goatanti-rabbitimmunoglobulin G (cat. no. SA00003-2) were obtained from ProteinTech Group, Inc. (Chicago, IL, USA); rabbit anti-phosphorylated (p)-GluR2 (Tyr876) (cat. no. 4027) antibody and rabbit anti-GluR2 (cat. no. 5306) antibody from Cell Signaling Technology, Inc. (Danvers, MA, USA). Mouse anti- $\beta$-actin (cat. no. sc-130300) from Santa Cruz Biotechnology, Inc. (Dallas, TX, USA). Horseradish peroxidase-conjugated anti-mouse or anti-rabbit secondary antibodies (cat. nos. 7072 and 7071) from Cell Signaling Technology, Inc. (Danvers, MA, USA). The random primers were obtained from Promega Corporation (Madison, WI, USA).

Culture of hippocampal neurons. Hippocampal neurons were primarily cultured as described by Yang et al (11). Following intraperitoneal injection of anesthetic (pentobarbital sodium, $3 \mu \mathrm{l} / \mathrm{g}$ ), Neonatal Sprague-Dawley rats aged $<24 \mathrm{~h}$ were
Table I. Specific primers for GluR2 and GAPDH used in reverse transcription-quantitative polymerase chain reaction.

\begin{tabular}{|c|c|c|}
\hline Gene & $\begin{array}{c}\text { Primer } \\
\text { sequence }\left(5^{\prime}-3^{\prime}\right)\end{array}$ & $\begin{array}{l}\text { Product } \\
\text { size (bp) }\end{array}$ \\
\hline GluR2 & $\begin{array}{l}\mathrm{F}: \text { CAAGTTCGCATACCTCTA } \\
\text { R: TTATCCCTTTCACAGTCC }\end{array}$ & 207 \\
\hline GAPDH & $\begin{array}{l}\text { F: TGAACGGGAAGCTCACTGG } \\
\text { R: GCTTCACCACCTTCTTGATGTC }\end{array}$ & 120 \\
\hline
\end{tabular}

GluR2, glutamate receptor 2; F, forward; R, reverse.

surface sterilized with disinfectant (75\% alcohol) and sacrificed by decapitation and the brains were extracted and placed in DMEM/F-12 medium at $0^{\circ} \mathrm{C}$. Bilateral hippocampi were harvested under an anatomical microscope. Following removal of the meninges, the brain tissue was cut into pieces and immersed in $0.125 \%$ trypsin ( $5 \mathrm{X}$ volume of brain tissue). The samples were digested in a $5 \% \mathrm{CO}_{2}$ incubator at $37^{\circ} \mathrm{C}$ for $15 \mathrm{~min}$. The digestion was terminated by adding DMEM/F-12 medium containing $10 \%$ serum. All samples were triturated and filtered with a 200-mesh screen. The resulting cell suspension was adjusted to $\sim 1 \times 10^{5} / \mathrm{ml}$ with DMEM/F-12 medium containing $10 \% \mathrm{FBS}$, seeded into 6 -well plates with polylysine-coated coverslips $(3 \mathrm{ml} /$ well $)$ and placed in a $5 \% \mathrm{CO}_{2}$ incubator at $37^{\circ} \mathrm{C}$ for $24 \mathrm{~h}$. The medium was subsequently replaced with neuronal medium (Neurobasal medium), supplemented with $2 \% \mathrm{~B}-27,100 \mathrm{U} / \mathrm{ml}$ penicillin and $100 \mu \mathrm{g} / \mathrm{ml}$ streptomycin. Half of the neuronal medium was replaced with fresh every 3 days, for 7-9 days, following which the purified neurons were harvested.

Identification of hippocampal neurons. MAP-2 is a neuron-specific protein and a marker of neuronal differentiation (12). At day 9 of in vitro culture, the hippocampal neurons on glass slides were fixed with $4 \%$ paraformaldehyde for $30 \mathrm{~min}$, washed three times with PBS for $5 \mathrm{~min}$ each time, permeabilized with $0.3 \%$ Triton $\mathrm{X}-100$ for $10 \mathrm{~min}$ and washed three times with PBS for 5 min each time. Cells were blocked with 3\% goat serum (OriGene Technologies, Inc., Beijing, China) at room temperature for $30 \mathrm{~min}$ and incubated with MAP-2 antibody $(1: 100)$ at $4^{\circ} \mathrm{C}$ overnight. Following three washes with $\mathrm{PBS}$ for 5 min each time, cells were incubated with a FITC-conjugated secondary antibody $(1: 100)$ at $37^{\circ} \mathrm{C}$ for $1 \mathrm{~h}$, followed by a further three washes with PBS for $5 \mathrm{~min}$ each time. Cells were counterstained with Hoechst 33258 for 5 min, washed three times with PBS for 5 min each time and observed under a fluorescence microscope.

Group assignment. Following 12 days of in vitro culture, hippocampal neurons were assigned to the following groups: Control, $\mathrm{Mg}^{2+}$-free, $\mathrm{NPY}+\mathrm{Mg}^{2+}$-free and BIBP3226+NPY+ $\mathrm{Mg}^{2+}$-free. In the control group, neurons were treated with normal extracellular fluid for $3 \mathrm{~h}$. In the $\mathrm{Mg}^{2+}$-free group, neurons were treated with $\mathrm{Mg}^{2+}$-free extracellular fluid for $3 \mathrm{~h}$. In the NPY $+\mathrm{Mg}^{2+}$-free group, neurons were incubated with cell culture fluid containing NPY at a final concentration of 

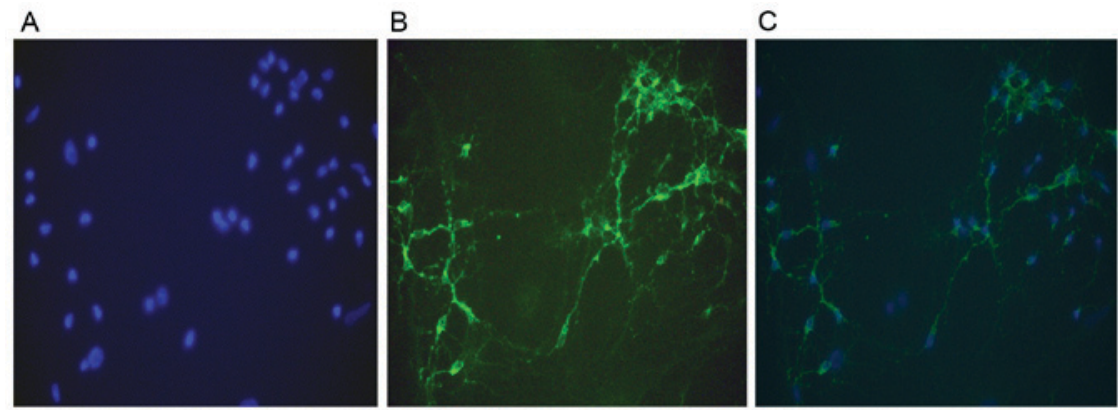

Figure 1. Primary cultured hippocampal neurons and cortical neurons demonstrated positive immunofluorescence staining with an MAP-2 antibody. (A) Blue fluorescent Hoechst 33258 nuclear staining, (B) green fluorescent MAP-2 staining and (C) merged image. Original magnification, x400. MAP-2, microtubule-associated protein 2 .

A
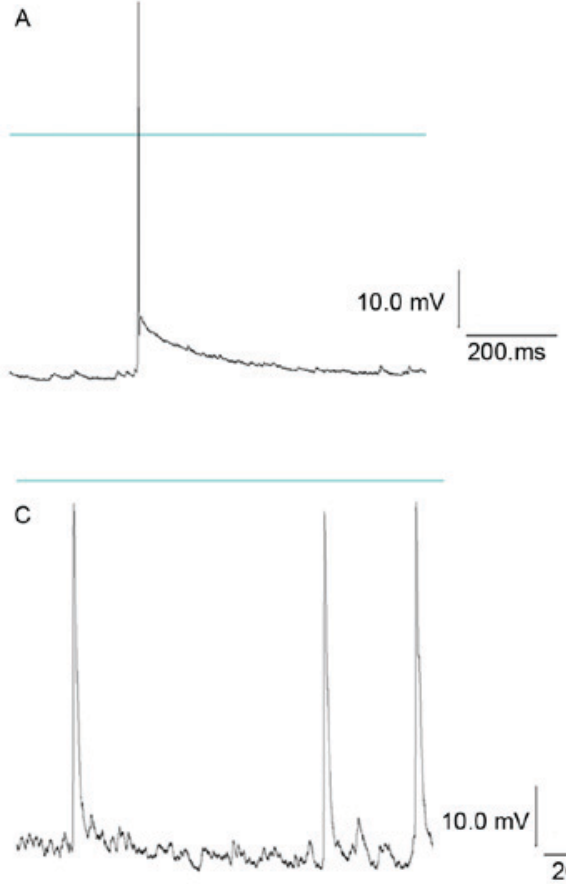

$10.0 \mathrm{mV}$

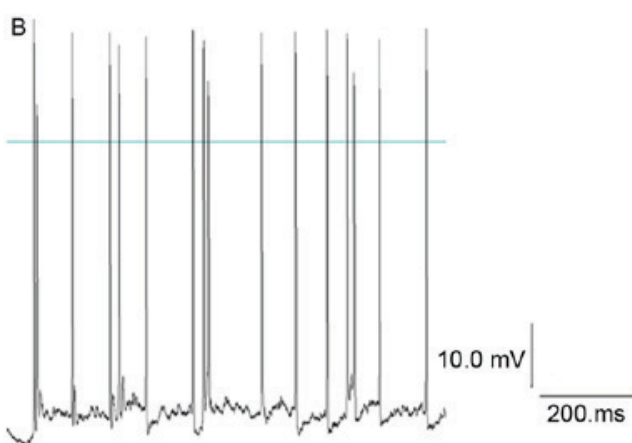

200.ms

200.ms

Figure 2. Action potential of rat hippocampal neurons treated with $\mathrm{Mg}^{2+}$-free and NPY extracellular fluid. Action potential of (A) control group and hippocampal neurons treated with (B) $\mathrm{Mg}^{2+}$-free and (C) $1 \mu \mathrm{M}$ NPY-containing extracellular fluid. NPY, neuropeptide Y.

$1 \mu \mathrm{mol} / 1$ for $30 \mathrm{~min}$ and then with $\mathrm{Mg}^{2+}$-free extracellular fluid for $3 \mathrm{~h}$. In the BIBP3226+NPY+ $\mathrm{Mg}^{2+}$-free group, neurons were incubated with cell culture fluid containing the NPY Y1 receptor blocker BIBP3226 at a final concentration of $1 \mu \mathrm{mol} / 1$ for $30 \mathrm{~min}$, with NPY at a final concentration of $1 \mu \mathrm{mol} / 1$ for $30 \mathrm{~min}$ and finally with $\mathrm{Mg}^{2+}$-free extracellular fluid for $3 \mathrm{~h}$. Afterwards, all groups received normal extracellular fluid for $1 \mathrm{~h}$. Cells were subsequently analyzed using the patch clamp technique, western blot analysis to measure GluR2 and phosphorylated GluR2 protein expression levels, and RT-qPCR to measure GluR2 mRNA expression levels.

Normal extracellular fluid comprised: $\mathrm{NaCl}, 147 \mathrm{mM}$; 4-(2-hydroxyethyl) -1-piperazineethanesulfonic acid (HEPES), $10 \mathrm{mM}$; glucose, $13 \mathrm{mM}$; $\mathrm{KCl}, 2 \mathrm{mM} ; \mathrm{CaCl}_{2}, 2 \mathrm{mM}$; and $\mathrm{MgCl}_{2}$, $2 \mathrm{mM}$; adjusted to pH 7.3 with $5 \mathrm{mM} \mathrm{NaOH}$; osmotic pressure 280-320 mM. $\mathrm{Mg}^{2+}$-free extracellular fluid comprised: $\mathrm{NaCl}$, $147 \mathrm{mM}$; HEPES, $10 \mathrm{mM}$; glucose, $13 \mathrm{mM}$; KC1, $2 \mathrm{mM}$; and $\mathrm{CaCl}_{2}, 2 \mathrm{mM}$; adjusted to pH 7.3 with $5 \mathrm{mM} \mathrm{NaOH}$; osmotic pressure 280-320 $\mathrm{mM}$.
Using the patch clamp technique, the action potential of neurons was recorded in the control, $\mathrm{Mg}^{2+}$-free and $\mathrm{NPY}+\mathrm{Mg}^{2+}$-free groups in accordance with the method of DeLorenzo et al (13).

Detection of AMPA current $\left(I_{A M P A}\right)$. $\mathrm{I}_{\mathrm{AMPA}}$ in neurons was recorded using the patch clamp technique $(14,15)$. Cell slides were placed in a $0.3 \mathrm{ml}$ bath and perfused with extracellular fluid at $2 \mathrm{ml} / \mathrm{min}$ to ensure fluid exchange in $2 \mathrm{~min}$. Cells were observed under an inverted microscope. Neurons with a distinct stereoscopic outline and smooth surface were used for the sealing experiment. With a three-dimensional manipulator, a glass microelectrode with impedance of 1-3 M $\Omega$ and pipette solution (Cs-gluconate, $110 \mathrm{mmol} / \mathrm{l}$; $\mathrm{CsCl}, 30 \mathrm{mmol} / \mathrm{l}$; HEPES, $10 \mathrm{mmol} / \mathrm{l}$; EGTA, $0.2 \mathrm{mmol} / \mathrm{l}$; NaCl, $8 \mathrm{mmol} / \mathrm{l}$; Mg-ATP, $2 \mathrm{mmol} / \mathrm{l}$; $\mathrm{Na}_{3} \mathrm{GTP}, 0.3 \mathrm{mmol} / \mathrm{l}$; phosphocreatine, $10 \mathrm{mmol} / \mathrm{l}$; $\mathrm{pH} 7.2$ adjusted with $\mathrm{NaOH}$ ) was connected to the cell surface. Negative pressure was increased until the cells ruptured. Capacitive current and series resistance were compensated and 
Table II. Comparison of frequency of action potential in three groups.

\begin{tabular}{lc}
\hline Group & Frequency (number/s) \\
\hline $\mathrm{Mg}^{2+}-$ free & $13.86 \pm 2.19^{\mathrm{a}}$ \\
$\mathrm{NPY}+\mathrm{Mg}^{2+}$-free & $1.89 \pm 0.69^{\mathrm{b}}$ \\
Control & $0.85 \pm 0.22$ \\
\hline
\end{tabular}

Data are expressed as the mean \pm standard deviation $(n=5)$. NPY, neuropeptide $\mathrm{Y}$. ${ }^{\mathrm{a}} \mathrm{P}<0.05$ vs. control group; ${ }^{\mathrm{b}} \mathrm{P}<0.05 \mathrm{vs} . \mathrm{Mg}^{2+}$-free. NPY, neuropeptide Y.

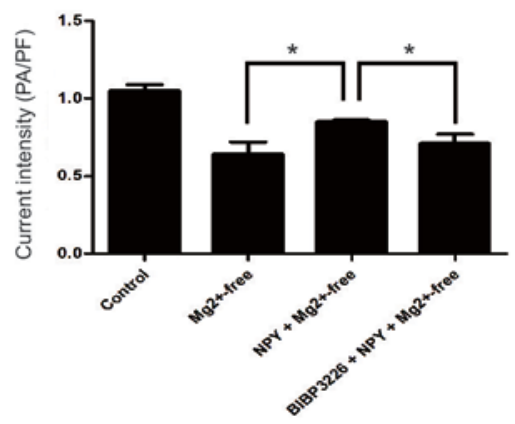

Figure 3. Current density of primary cultured rat hippocampal neurons induced by $\alpha$-amino-3-hydroxy-5-methyl-4-isoxazolepropionic acid in control, $\mathrm{Mg}^{2+}$-free, NPY+ $\mathrm{Mg}^{2+}$-free and BIBP3226+NPY+ $\mathrm{Mg}^{2+}$-free groups. Data are expressed as the mean \pm standard deviation $(n=5) .{ }^{*} \mathrm{P}<0.05$. NPY, neuropeptide Y.

a whole-cell recording created. Voltage was held at $-70 \mathrm{mV}$ for $5 \mathrm{~min}$, following which the intracellular fluid and pipette solution were completely replaced, and $100 \mu \mathrm{mol} / 1$ AMPA was administered to induce inward current. This current was $\mathrm{I}_{\mathrm{AMPA}}$. To further verify this, AMPA was measured following elution and the membrane current returned to normal. When $100 \mu \mathrm{mol} / 1$ AMPA was administered, $10 \mu \mathrm{mol} / 1$ 6-cyano-7-nitroquinoxaline-2,3-dione was used to block the AMPA receptor and the original inward current could not be detected. Thus, the recorded current was $\mathrm{I}_{\mathrm{AMPA}}$. To exclude error in different cells, peak current density was measured using $\mathrm{pA} / \mathrm{pF}$.

Western blot analysis of GluR2 protein expression and phosphorylation levels. Cells were harvested, washed with PBS, lysed with precooled radioimmunoprecipitation assay lysis buffer (Beyotime Institute of Biotechnology, Jiangsu, China) and centrifuged at $12,000 \times \mathrm{g}$ at $4^{\circ} \mathrm{C}$ for $10 \mathrm{~min}$. The supernatant, containing the total proteins from the hippocampal neurons, was collected. Protein concentrations were determined by the Lowry method. Total proteins $(100 \mu \mathrm{g})$ were separated by electrophoresis on $5 \%$ stacking and $10 \%$ separating gels at $100 \mathrm{~V}$ for $150 \mathrm{~min}$. Separated proteins were transferred onto polyvinylidene difluoride membranes. Membranes were blocked by $5 \%$ non-fat milk in $0.01 \mathrm{~mol} / 1$ PBS at room temperature for $2 \mathrm{~h}$, incubated with primary antibody at $4^{\circ} \mathrm{C}$ overnight $(1: 1,000)$, washed three times, incubated with a horseradish peroxidase-conjugated secondary antibody (1:400) at $37^{\circ} \mathrm{C}$ for $1 \mathrm{~h}$ and washed three times. Protein bands
Table III. Comparison of amplitude of action potential in three groups.

\begin{tabular}{lc} 
Group & Amplitude $(\mathrm{mV})$ \\
\hline $\mathrm{Mg}^{2+}-$ free & $81.25 \pm 5.18^{\mathrm{a}}$ \\
$\mathrm{NPY}+\mathrm{Mg}^{2+}$-free & $40.06 \pm 2.31^{\mathrm{b}}$ \\
Control & $35.56 \pm 1.23$
\end{tabular}

Data are expressed as the mean \pm standard deviation $(n=5) .{ }^{a} \mathrm{P}<0.05$ vs. control group; ${ }^{\mathrm{b}} \mathrm{P}<0.05$ vs. $\mathrm{Mg}^{2+}$-free. NPY, neuropeptide Y. NPY, neuropeptide $\mathrm{Y}$.

were visualized with 3,3'-diaminobenzidine (Sangon Biotech Co., Ltd., Shanghai, China) and the gray values were measured and quantitatively analyzed with BandScan version 5.0 (Glyko; BioMarin Pharmaceutical, Inc., San Rafael, CA, USA). The experiments were performed in triplicate.

RT-qPCR analysis of GluR2 mRNA expression levels. Following the removal of cell medium, $1 \mathrm{ml} \mathrm{TRIzol}{ }^{\circledR}$ was added to each well. The samples were triturated and placed in a ribozyme-free centrifuge tube for $5 \mathrm{~min}$. Subsequently, $0.2 \mathrm{ml}$ chloroform was added to each tube, which were vigorously agitated for $15 \mathrm{sec}$, rested for $5 \mathrm{~min}$ and centrifuged at $13,800 \times \mathrm{g}$ at $4^{\circ} \mathrm{C}$ for $15 \mathrm{~min}$. The supernatant was transferred to a new centrifuge tube, treated with an equal volume of isopropanol and centrifuged at $13,800 \times \mathrm{g}$ at $4^{\circ} \mathrm{C}$ for $10 \mathrm{~min}$. A feathery white precipitate was observed at the bottom of the tube, the supernatant was discarded and $1 \mathrm{ml} 75 \%$ ethanol [prepared with diethyl pyrocarbonate (DEPC)-treated water] was added. The precipitate was washed and centrifuged at $5,400 \times \mathrm{g}$ at $4^{\circ} \mathrm{C}$ for $5 \mathrm{~min}$. Following removal of the supernatant, the sample was air-dried for 3-5 min. RNA was fully dissolved with 20-30 $\mu \mathrm{l}$ of DEPC-treated water and its purity measured using an ultraviolet spectrophotometer. cDNA was synthesized using the EasyScript First-strand cDNA synthesis superMix kit (Beijing TransGen Biotech Co., Ltd., Beijing, China). Rat GluR2 primer sequences were synthesized by Promega Corporation (Table I). The reaction mixture was as follows: 2X UltraSYBR ${ }^{\circledR}$ Mixture (with ROX), $10 \mu 1$; forward primer $(10 \mu \mathrm{mol} / \mathrm{l}), 1 \mu \mathrm{l}$; reverse primer $(10 \mu \mathrm{mol} / \mathrm{l})$, $1 \mu \mathrm{l}$; cDNA, $8 \mu \mathrm{l}$. The total reaction volume was $20 \mu \mathrm{l}$. qPCR cycling conditions were as follows: An initial predenaturation step at $95^{\circ} \mathrm{C}$ for $10 \mathrm{~min}$, followed by 40 cycles of denaturation at $95^{\circ} \mathrm{C}$ for $15 \mathrm{sec}$, annealing at $58^{\circ} \mathrm{C}$ for $20 \mathrm{sec}$ and extension at $72^{\circ} \mathrm{C}$ for $27 \mathrm{sec}$. Following amplification, results were analyzed with an ABI 7300 Real-Time PCR system (Applied Biosystems; Thermo Fisher Scientific, Inc.). The relative value (RQ value) of target gene expression to the internal reference gene GAPDH was detected and calculated (16).

Statistical analysis. The data were analyzed with SPSS version 10.0 (SPSS, Inc., Chicago, IL, USA) using tests for normality and homogeneity of variance. Data that obeyed normality and homogeneity of variance were analyzed using analysis of variance for completely random design. Paired comparison was conducted with the least significant difference post hoc test. 

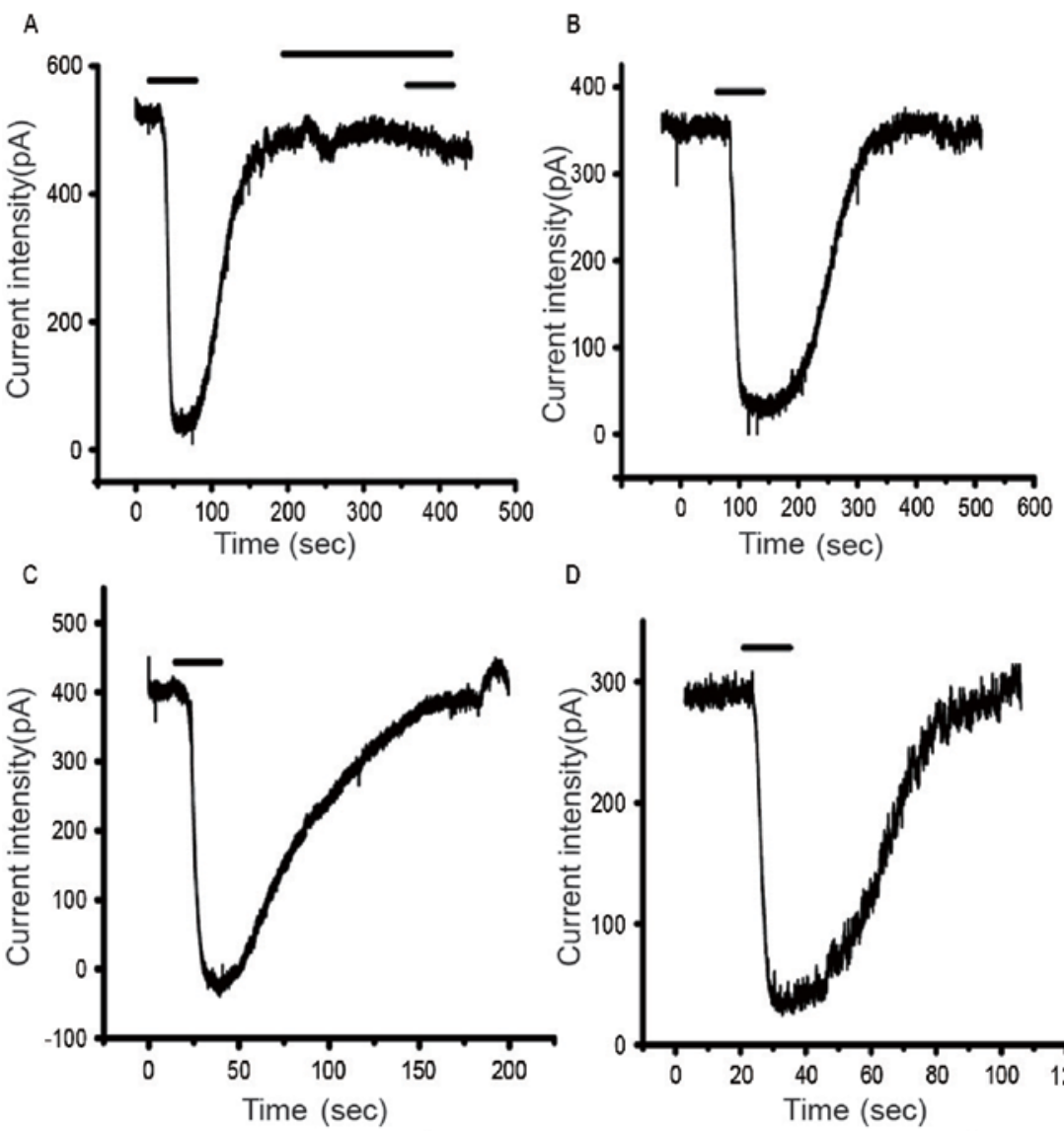

D

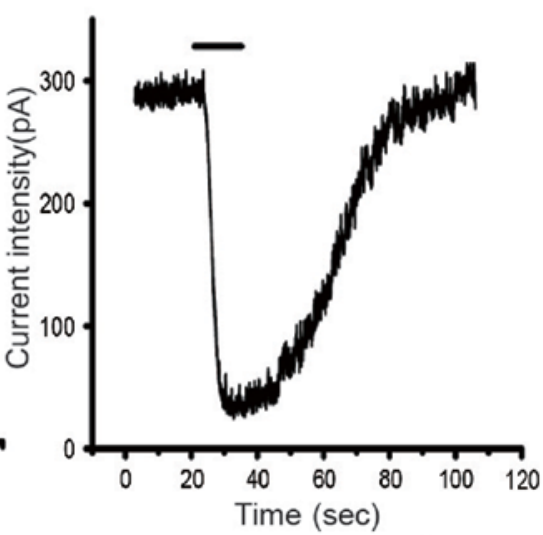

Figure 4. Current of primary cultured rat hippocampal neurons induced by $\alpha$-amino-3-hydroxy-5-methyl-4-isoxazolepropionic acid. (A) Control, (B) $\mathrm{Mg}^{2+}$-free, (C) NPY $+\mathrm{Mg}^{2+}$-free and (D) BIBP3226+NPY $+\mathrm{Mg}^{2+}$-free groups. NPY, neuropeptide Y.

Data were expressed as the mean \pm standard deviation. $\mathrm{P}<0.05$ was considered to indicate a statistically significant difference.

\section{Results}

NPY suppresses epileptiform discharges in hippocampal neurons. Primary cultured hippocampal neurons had axons and dendrites. Immunostaining of MAP-2 revealed that neuronal purity was $>95 \%$ (Fig. 1). The patch clamp technique records the normal action potential of hippocampal neurons. Following treatment with $\mathrm{Mg}^{2+}$-free extracellular fluid for $3 \mathrm{~h}$ followed by normal extracellular fluid, a continuously stable action potential was detected in the neurons; the frequency and amplitude appeared greater compared with the control group, indicating spontaneous epileptiform discharges in the neurons. Following treatment with NPY $1 \mu \mathrm{mol} / 1$ for $30 \mathrm{~min}$, $\mathrm{Mg}^{2+}$-free extracellular fluid for $3 \mathrm{~h}$ and normal extracellular fluid, the frequency and amplitude of the action potential were significantly reduced in NPY $+\mathrm{Mg}^{2+}$-free group compared with the $\mathrm{Mg}^{2+}$-free group ( $\mathrm{P}<0.05$; Fig. 2; Tables II and III). This suggested that NPY significantly inhibited abnormal discharges in hippocampal neurons.

Epileptiform discharges in hippocampal neurons inhibit the function of AMPA receptor GluR2 subunit. $\mathrm{I}_{\mathrm{AMPA}}$ detection results demonstrated that peak current density was significantly reduced in the $\mathrm{Mg}^{2+}$-free group compared with the control group $(\mathrm{P}<0.05$; Figs. 3 and 4; Table IV). Protein expression levels of GluR2 were slightly reduced $(\mathrm{P}>0.05$; Fig. 5; Table V) and those of p-GluR2 were significantly greater $\left(\mathrm{P}<0.05\right.$; Fig. 6 ; Table VI) in the $\mathrm{Mg}^{2+}$-free group compared with the control group. GluR2 mRNA expression levels were significantly reduced in the $\mathrm{Mg}^{2+}$-free group compared with the control group $(\mathrm{P}<0.05$; Fig. 7; Table VII). These results suggested that epileptiform discharges in hippocampal neurons may induce the suppression of the function of the GluR2 subunit.

$N P Y$ relieves the inhibition of GluR2 subunit function induced by epileptiform discharges in hippocampal neurons. Peak current density was significantly greater in the NPY $+\mathrm{Mg}^{2+}$-free group compared with the $\mathrm{Mg}^{2+}$-free group $(\mathrm{P}<0.05$; Figs. 3 and 4; Table IV). Protein expression levels of GluR2 were slightly increased ( $\mathrm{P}>0.05$; Fig. 5; Table V) and those of p-GluR2 were significantly reduced $(\mathrm{P}<0.05$; Fig. 6 ; Table VI) in the $\mathrm{NPY}+\mathrm{Mg}^{2+}$-free group compared with the $\mathrm{Mg}^{2+}$-free group. GluR2 mRNA expression levels were significantly greater in the NPY+ $\mathrm{Mg}^{2+}$-free group compared with the $\mathrm{Mg}^{2+}$-free group $(\mathrm{P}<0.05$; Fig. 7; Table VII). These findings indicated that NPY weakened the inhibition of GluR2 function induced by epileptiform discharges in neurons.

NPY regulates GluR2 subunit function possibly via the $Y 1$ receptor. Peak current density was significantly reduced in the BIBP3226+NPY+Mg ${ }^{2+}$-free group compared with the $\mathrm{NPY}+\mathrm{Mg}^{2+}$-free group $(\mathrm{P}<0.05$; Figs. 3 and 4; Table IV). Protein 
Table IV. Current density of primary cultured hippocampal neurons induced by $\alpha$-amino-3-hydroxy-5-methyl-4-isoxazol epropionic acid.

\begin{tabular}{lc}
\hline Group & Current density $(\mathrm{pA} / \mathrm{pF})$ \\
\hline Control & $1.05 \pm 0.04$ \\
$\mathrm{Mg}^{2+}$-free & $0.64 \pm 0.08^{\mathrm{a}}$ \\
$\mathrm{NPY}+\mathrm{Mg}^{2+}$-free & $0.85 \pm 0.01^{\mathrm{b}}$ \\
BIBP3226+NPY+Mg & $0.71 \pm 0.06^{\mathrm{a}}$ \\
\hline
\end{tabular}

Data are expressed as the mean \pm standard deviation $(n=5)$. ${ }^{\mathrm{a}} \mathrm{P}<0.05$ vs. control group; ${ }^{\mathrm{b}} \mathrm{P}<0.05$ vs. $\mathrm{Mg}^{2+}$-free and $\mathrm{BIBP} 3226+\mathrm{NPY}+\mathrm{Mg}^{2+}$-free groups. NPY, neuropeptide $\mathrm{Y}$.
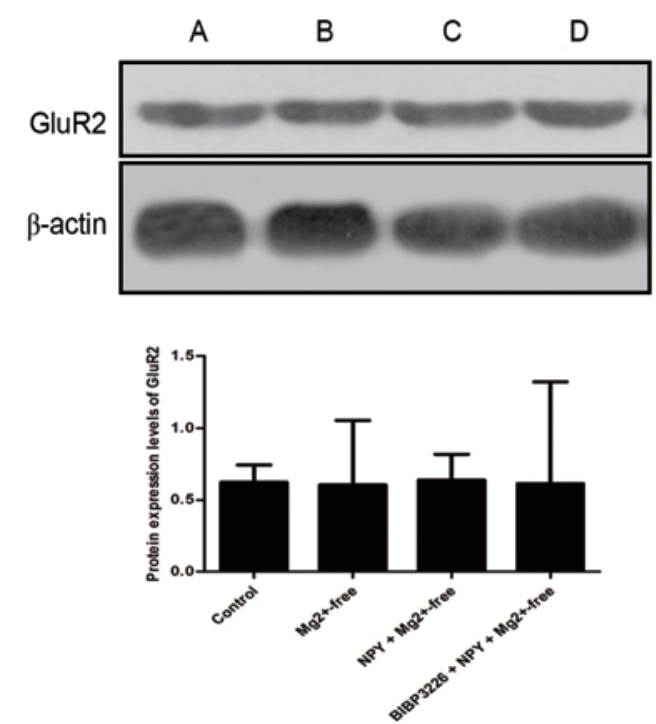

Figure 5. Protein expression of GluR2 as assessed by western blot analysis. (A) Control, (B) $\mathrm{Mg}^{2+}$-free, (C) BIBP3226+NPY+ $\mathrm{Mg}^{2+}$-free and (D) NPY $+\mathrm{Mg}^{2+}$-free groups. GluR2, glutamate receptor 2; NPY, neuropeptide Y. Protein expression levels of GluR2 as assessed by densitometry following western blot analysis. Data are expressed as the mean \pm standard deviation $(\mathrm{n}=5)$. GluR2, glutamate receptor 2; NPY, neuropeptide Y.

expression levels of GluR2 were slightly reduced $(\mathrm{P}>0.05$; Fig. 5; Table V) and those of p-GluR2 were significantly greater $\left(\mathrm{P}<0.05\right.$; Fig. 6; Table VI) in the BIBP3226+NPY+ $\mathrm{Mg}^{2+}$-free group compared with the $\mathrm{NPY}+\mathrm{Mg}^{2+}$-free group. GluR2 mRNA expression levels were significantly reduced in the BIBP3226+NPY+Mg ${ }^{2+}$-free group compared with the $\mathrm{NPY}+\mathrm{Mg}^{2+}$-free group $(\mathrm{P}<0.05$; Fig. 7; Table VII).

\section{Discussion}

Epilepsy is a brain disorder characterized by the abnormal discharge of neurons in the brain. The pathogenesis of epilepsy remains unclear and it may be that a variety of factors contribute to its occurrence. Neuronal loss occurs, and is accompanied by a large number of abnormal discharge neurons in the lesion. Ion channel dysfunction in cells causes seizures; this is the 'epileptic neuron' theory $(17,18)$. The hippocampus is the site of a high concentration of neurons and
Table V. Protein expression levels of GluR2, as assessed by western blot analysis.

\begin{tabular}{lc}
\hline Group & GluR2 \\
\hline Control & $0.6241 \pm 0.15$ \\
$\mathrm{Mg}^{2+}$-free & $0.6057 \pm 0.25$ \\
$\mathrm{NPY}+\mathrm{Mg}^{2+}$-free & $0.6397 \pm 0.18$ \\
BIBP3226+NPY $+\mathrm{Mg}^{2+}$-free & $0.6146 \pm 0.21$
\end{tabular}

Data are expressed as the mean \pm standard deviation $(n=5)$. GluR2, glutamate receptor 2; NPY, neuropeptide Y.

Table VI. Protein expression levels of p-GluR2, as assessed by western blot analysis.

\begin{tabular}{lc}
\hline Group & p-GluR2 \\
\hline Control & $0.3879 \pm 0.21$ \\
$\mathrm{Mg}^{2+}-$ free & $1.3173 \pm 0.17^{\mathrm{a}}$ \\
$\mathrm{NPY}+\mathrm{Mg}^{2+}-$ free & $0.8918 \pm 0.07^{\mathrm{b}}$ \\
$\mathrm{BIBP} 3226+\mathrm{NPY}+\mathrm{Mg}^{2+}$-free & $1.0483 \pm 0.08^{\mathrm{a}}$ \\
\hline
\end{tabular}

Data are expressed as the mean \pm standard deviation $(n=5)$. ${ }^{a} \mathrm{P}<0.05$ vs. control group; ${ }^{\mathrm{b}} \mathrm{P}<0.05$ vs. $\mathrm{Mg}^{2+}$-free and $\mathrm{BIBP} 3226+\mathrm{NPY}+\mathrm{Mg}^{2+}$-free groups. GluR2, glutamate receptor 2; $\mathrm{p}$, phosphorylated; NPY, neuropeptide Y.

possesses an important role in the pathogenesis of epilepsy: Hippocampal sclerosis is a common cause of temporal lobe epilepsy. The structure of the nervous system is complex and there are numerous factors restricting its study in vivo. Electrophysiological testing, including the patch clamp technique, is not easy to implement. Hippocampal slices and neuronal cultures have attracted increasing attention in the study of epilepsy (19).

$\mathrm{Mg}^{2+}$ serves an important role in maintaining normal electric activity in the central nervous system (20). DeLorenzo et al (13) reported that the removal of $\mathrm{Mg}^{2+}$ from the cell medium, or treatment with $\mathrm{Mg}^{2+}$-free extracellular fluid for $3 \mathrm{~h}$, may successfully induce spontaneous recurrent epileptiform discharges in primary cultured hippocampal neurons. Such cultured neurons do not possess real anatomical connections or clinical manifestations, but the spontaneous recurrent action potential evoked by $\mathrm{Mg}^{2+}$-free conditions is similar to the electrophysiological activity during epileptic seizures and anti-epileptic drugs may prevent such action potentials (21-22). This technique has been used in studies of the biochemical, electrophysiological and molecular mechanisms of acquired epilepsy (23).

NPY is widely distributed in the central nervous system (cerebral cortex, hippocampus, thalamus, hypothalamus and brain stem) and the peripheral nervous system. In the central nervous system, NPY concentration is greatest in the hippocampus. NPY has an anti-epileptic effect $(24,25)$ and a protective effect on cerebellum neuronal cells cultured in vitro. These protective effects are weakened following blocking of 

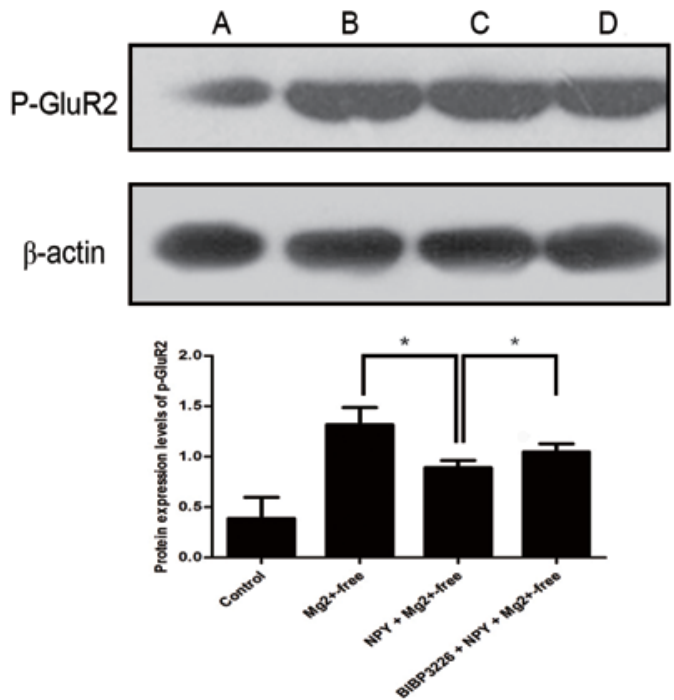

Figure 6. Protein expression of p-GluR2 as assessed by western blot analysis. (A) Control, (B) $\mathrm{Mg}^{2+}$-free, (C) BIBP3226+NPY+ $\mathrm{Mg}^{2+}$-free and (D) NPY $+\mathrm{Mg}^{2+}$-free groups. GluR2, glutamate receptor 2; , phosphorylated; NPY, neuropeptide Y. Protein expression levels of p-GluR2 as assessed by densitometry following western blot analysis. Data are expressed as the mean \pm standard deviation $(\mathrm{n}=5)$. ${ }^{*} \mathrm{P}<0.05$. GluR2, glutamate receptor $2 ; \mathrm{p}$, phosphorylated; NPY, neuropeptide Y.

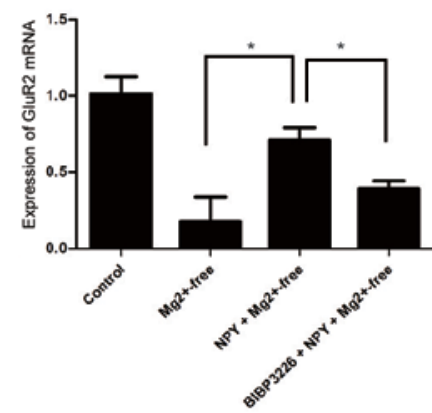

Figure 7. mRNA expression levels of GluR2, as assessed by reverse transcription-quantitative polymerase chain reaction. Data are expressed as the mean \pm standard deviation $(n=5)$. ${ }^{*} \mathrm{P}<0.05$ vs. control group. GluR2, glutamate receptor; NPY, neuropeptide Y.

the NPY Y1 and Y2 receptors, suggesting that NPY exerts neuroprotective effects via the Y1 and Y2 receptors (26-28). In the present study, epileptiform discharges were detected in hippocampal neurons of rats following treatment with $\mathrm{Mg}^{2+}$-free extracellular fluid. Following treatment with NPY and $\mathrm{Mg}^{2+}$-free extracellular fluid, epileptiform discharges were notably weakened, indicating that NPY may suppress epileptiform discharges in neurons.

Excitatory and inhibitory neurotransmitters present in the central nervous system are responsible for the balance of a complex network and maintain normal cerebral function. Following excitatory neurotransmitter increases, or inhibitory neurotransmitter decreases, the ratio may become unbalanced. GluR functional alteration is one of the important causes of epilepsy (29). Excessive activation of GluRs may cause neuronal damage, a variety of neurological damage, and chronic neurodegenerative diseases, including cerebral ischemia and hypoxia, epilepsy and brain trauma. Previous studies have confirmed
Table VII. mRNA expression levels of GluR2, as assessed by reverse transcription-quantitative polymerase chain reaction.

\begin{tabular}{ll}
\hline Group & GluR2 \\
\hline Control & $1.016 \pm 0.11$ \\
$\mathrm{Mg}^{2+}$-free & $0.179 \pm 0.16^{\mathrm{a}}$ \\
$\mathrm{NPY}+\mathrm{Mg}^{2+}$-free & $0.713 \pm 0.08^{\mathrm{b}}$ \\
$\mathrm{BIBP} 3226+\mathrm{NPY}+\mathrm{Mg}^{2+}$-free & $0.394 \pm 0.05^{\mathrm{a}}$
\end{tabular}

Data are expressed as the mean \pm standard deviation $(n=5)$. ${ }^{\mathrm{a}} \mathrm{P}<0.05$ vs. control group; ${ }^{\mathrm{b}} \mathrm{P}<0.05$ vs. $\mathrm{Mg}^{2+}$-free and $\mathrm{BIBP} 3226+\mathrm{NPY}+\mathrm{Mg}^{2+}$-free groups. GluR2, glutamate receptor 2; NPY, neuropeptide Y.

that following epilepsy, a massive release of glutamate and overactivation of its receptors causes a $\mathrm{Ca}^{2+}$ influx, followed by delayed neuronal death and secondary injury $(30,31)$.

GluR may be divided into metabotropic types (coupled with $\mathrm{G}$ protein) and ionotropic types (containing ion channels). In accordance with pharmacological properties, molecular characteristics and electrophysiological properties, ionotropic GluR may be divided into three subtypes: AMPA receptor, N-methyl-D-aspartate receptor and kainate receptor (32).

The AMPA receptor, a type of ion channel protein, may be regulated by membrane potential, glutamate and AMPA. It is composed of four subunits (GluR1, 2, 3 and 4) encoded by different genes (33). Due to the low calcium ion permeability induced by mRNA $\mathrm{Q} / \mathrm{R}$ site editing, the relative content of GluR2 subunit in the AMPA receptor determines the functional properties of AMPA receptors. An AMPA receptor containing the GluR2 subunit is permeable to monovalent cations $\left(\mathrm{Na}^{+}\right.$, $\mathrm{K}^{+}$), but not to divalent cations $\left(\mathrm{Ca}^{2+}\right)$; an AMPA receptor without a GluR2 subunit is highly permeable to $\mathrm{Ca}^{2+}(34,35)$. The primary features of AMPA receptors are therefore determined by GluR2 and GluR2 protein downregulation is considered to be a molecular switch (36). Blocking or reducing GluR2 expression forms a calcium-permeable AMPA receptor, increases $\mathrm{Ca}^{2+}$ influx and enhances endogenous glutamate excitotoxicity.

In the central nervous system, the GluR2 subunit is highly expressed in various neurons. Under normal conditions, GluR2 is abundant in synapses. Following hypoxia, the content of GluR2 on the membrane surface of the neuron is significantly decreased and the number of synapses containing GluR2 reduced, indicating that the mechanism of blocking $\mathrm{Ca}^{2+}$ influx has markedly weakened (37).

The results of the present study demonstrated that, following treatment with $\mathrm{Mg}^{2+}$-free extracellular fluid, GluR2 subunit mRNA expression levels were decreased, but protein phosphorylation levels were increased, suggesting that the GluR2 subunit had been reduced or its activity deceased in neuronal membranes. Abnormal activation of neurons diminished AMPA receptor GluR2 subunit expression. It has previously been demonstrated that without a GluR2 subunit, the $\mathrm{Ca}^{2+}$ permeability of AMPA receptors increases and a large $\mathrm{Ca}^{2+}$ influx may be detected, able to activate a series of 
intracellular protein kinases or immediate early genes (38) and resulting in a decrease in GluR2 subunit expression. Grooms et al (39) hypothesized that the decreased GluR2 expression induced by epileptic seizure caused an increase in the $\mathrm{Ca}^{2+}$ permeability of AMPA receptors, resulting in $\mathrm{Ca}^{2+}$ overload, an important cause of delayed neuronal death in hippocampal neurons. Sanchez et al (40) demonstrated that perinatal hypoxia-induced seizures increased the $\mathrm{Ca}^{2+}$ permeability of AMPA receptors.

The present study used a whole cell patch clamp technique to record $\mathrm{I}_{\mathrm{AMPA}}$ in neurons cultured in vitro. AMPA is a selective agonist of the exogenous AMPA receptor, and is synthesized artificially. AMPA binding to AMPA receptor depolarizes the cell membrane and opens ion channels. Results from the present study demonstrated that $\mathrm{I}_{\mathrm{AMPA}}$ was reduced in the $\mathrm{Mg}^{2+}$-free group compared with the control group. The decreased degree of $I_{\text {AMPA }}$ was markedly diminished in the $\mathrm{NPY}+\mathrm{Mg}^{2+}$-free group compared with the $\mathrm{Mg}^{2+}$-free group This effect was inhibited by BIBP3226. These results indicated that epileptiform discharges in cells may induce a reduction in the functions of AMPA receptors.

The AMPA receptor is a membrane receptor, the function of which may be regulated by multiple internal and external cell processes; phosphorylation has the greatest influence on its function (41). PDZ domain-containing proteins may interact with the PDZ structural domain at the GluR2 C terminus following binding to activate protein kinase $\mathrm{C}-\alpha$, which induces ser880 phosphorylation at the GluR2 $\mathrm{C}$ terminus and endocytosis of the GluR2 complex, reducing the expression of AMPA receptor GluR2 subunit on the surface of neurons and thus serving an important role in AMPA receptor expression and transport $(42,43)$.

$\mathrm{I}_{\mathrm{AMPA}}$ is the most direct indicator reflecting electrophysiological alterations in AMPA receptors. A decrease in $\mathrm{I}_{\mathrm{AMPA}}$ reflects a reduction in receptor function. During epileptiform discharges, $\mathrm{I}_{\mathrm{AMPA}}$ falls, indicating that AMPA receptor activity is reduced. Based on the RT-qPCR and western blot analysis results, it is hypothesized that epileptiform discharges in hippocampal neurons led to the phosphorylation of the AMPA receptor GluR2 subunit on the membrane surface and suppressed GluR2 subunit mRNA. The AMPA receptor GluR2 subunit on the membrane surface was transported into cells, so AMPA receptor activity on the membrane surface diminished. Therefore, neuron total protein detection did not alter significantly between groups. The lack of the normal AMPA receptor GluR2 subunit pathway on the membrane surface causes a high $\mathrm{Ca}^{2+}$ permeability and may induce a rapid $\mathrm{Ca}^{2+}$ influx, $\mathrm{Ca}^{2+}$ concentration increase and a series of pathological reactions.

$\mathrm{I}_{\mathrm{AMPA}}$ and GluR2 mRNA expression levels were significantly greater, but GluR2 protein phosphorylation levels were significantly reduced in the $\mathrm{NPY}+\mathrm{Mg}^{2+}$-free group compared with the $\mathrm{Mg}^{2+}$-free group. It is hypothesized that NPY may inhibit the alterations in AMPA receptor function induced by epileptiform discharges, suggesting that NPY may have affected AMPA receptor functions and avoided excessive reduction of $\mathrm{I}_{\mathrm{AMPA}}$ by regulating the GluR2 subunit. The inhibitory effect of NPY was suppressed by treatment with the Y1 receptor blocker BIBP3226. NPY exerts different effects by binding to different receptors; NPY receptors belong to the G protein-coupled receptor family (44) and contain $Y 1$, Y2, Y3, Y4 and Y5 subtypes in humans. Different NPY receptors are distributed in different regions of the body; the Y1 receptor is primarily expressed in the cerebral cortex, amygdala and hippocampus (45). Previous studies on the anti-epileptic effect of NPY have primarily focused on Y2 and Y5 receptors $(46,47)$. It is hypothesized that NPY exerted an anti-epileptic effect in the present study via the $\mathrm{Y} 1$ receptor expressed on the membrane surface of hippocampal neurons. This may be a pharmacological mechanism underlying the anti-epileptic effect of NPY.

In conclusion, the present study investigated the functional alterations in the AMPA receptor GluR2 subunit and the effect of NPY on these alterations during epileptiform discharges in hippocampal neurons, to provide a theoretical basis for specifically blocking pathological process and for the design of therapeutic agents with low toxicity for the treatment of epilepsy.

\section{References}

1. Rocha AK, de Lima E, Amaral FG, Peres R, Cipolla-Neto J and Amado D: Pilocarpine-induced epilepsy alters the expression and daily variation of the nuclear receptor ROR $\alpha$ in the hippocampus of rats. Epilepsy Behav 55: 38-46, 2015.

2. Muldoon SF, Villette V, Tressard T, Malvache A, Reichinnek S, Bartolomei F and Cossart R: GABAergic inhibition shapes interictal dynamics in awake epileptic mice. Brain 138: 2875-2890, 2015.

3. Tsamis KI, Mytilinaios DG, Njau SN and Baloyannis SJ: Glutamate receptors in human caudate nucleus in normal aging and Alzheimer's disease. Curr Alzheimer Res 10: 469-475, 2013.

4. Ettinger AB, LoPresti A, Yang H, Williams B, Zhou S, Fain R and Laurenza A: Psychiatric and behavioral adverse events in randomized clinical studies of the noncompetitive AMPA receptor antagonist perampanel. Epilepsia 56: 1252-1263, 2015.

5. Harlow DE, Saul KE, Komuro H and Macklin WB: Myelin proteolipid protein complexes with $\alpha \mathrm{v}$ integrin and AMPA receptors in vivo and regulates AMPA-dependent oligodendrocyte progenitor cell migration through the modulation of cell-surface GluR2 expression. J Neurosci 35: 12018-12032, 2015.

6. Friedman LK, Velísková J, Kaur J, Magrys BW and Liu H. GluR2(B) knockdown accelerates CA3 injury after kainate seizures. J Neuropathol Exp Neurol 62: 733-750, 2003.

7. Tatemoto K, Carlquist M and Mutt V: Neuropeptide Y-a novel brain peptide with structural similarities to peptide YY and pancreatic polypeptide. Nature 296: 659-660, 1982.

8. Woldbye DP and Kokaia M: Neuropeptide Y and seizures: Effects of exogenously applied ligands. Neuropeptides 38: 253-260, 2004.

9. Malva JO, Xapelli S, Baptista S, Valero J, Agasse F, Ferreira R and Silva AP: Multifaces of neuropeptide Y in the brain-neuroprotection, neurogenesis and neuroinflammation. Neuropeptides 46: 299-308, 2012.

10. Vezzani A and Sperk G: Overexpression of NPY and Y2 receptors in epileptic brain tissue: An endogenous neuroprotective mechanism in temporal lobe epilepsy? Neuropeptides 38: 245-252, 2004.

11. Yang S, Zhou W, Zhang Y, Yan C and Zhao Y: Effects of Liuwei Dihuang decoction on ion channels and synaptic transmission in cultured hippocampal neuron of rat. J Ethnopharmacol 106: 166-172, 2006.

12. Atalay B, Caner H, Can A and Cekinmez M: Attenuation of microtubule associated protein- 2 degradation after mild head injury by mexiletine and calpain-2 inhibitor. Br J Neurosurg 21: 281-287, 2007.

13. DeLorenzo RJ, Sombati S and Coulter DA: Effects of topiramate on sustained repetitive firing and spontaneous recurrent seizure discharges in cultured hippocampal neurons. Epilepsia 41 (Suppl 1): S40-S44, 2000.

14. Rozov A, Sprengel R and Seeburg PH: GluA2-lacking AMPA receptors in hippocampal CA1 cell synapses: Evidence from gene-targeted mice. Front Mol Neurosci 5: 22, 2012. 
15. Rozov A,Zivkovic AR and Schwarz MK: Homerl gene products orchestrate $\mathrm{Ca}^{(2+)}$-permeable AMPA receptor distribution and LTP expression. Front Synaptic Neurosci 4: 4: 2012.

16. Curtis KM, Gomez LA, Rios C, Garbayo E, Raval AP, Perez-Pinzon MA and Schiller PC: EF1alpha and RPL13a represent normalization genes suitable for RT-qPCR analysis of bone marrow derived mesenchymal stem cells. BMC Mol Biol 11: 61, 2010.

17. Dudek FE and Rogawski MA: The epileptic neuron redux. Epilepsy Curr 2: 151-152, 2002.

18. Bernard C, Anderson A, Becker A, Poolos NP, Beck H and Johnston D: Acquired dendritic channelopathy in temporal lobe epilepsy. Science 305: 532-535, 2004.

19. Kato K, Sekino Y, Takahashi H, Yasuda H and Shirao T: Increase in AMPA receptor-mediated miniature EPSC amplitude after chronic NMDA receptor blockade in cultured hippocampal neurons. Neurosci Lett 418: 4-8, 2007.

20. Solger J, Heinemann U and Behr J: Electrical and chemical long-term depression do not attenuate low-Mg2+-induced epileptiform activity in the entorhinal cortex. Epilepsia 46: 509-516, 2005.

21. Hu Y, Jiang L, Chen H and Zhang X: Expression of AMPA receptor subunits in hippocampus after status convulsion. Childs Nerv Syst 28: 911-918, 2012.

22. Ma YX, Yin JB, Fan XT, Xu HW, An N, Wan ZB, Li ZF, Liu GL, Zhang YH and Yang Hui: Establishment of kainic acid induced temporal lobe epilepsy in rat and study of its neurogenesis Acta Academiae Medicinae Militaris Tertiae 29: 872-875, 2007.

23. Sombati S and Delorenzo RJ: Recurrent spontaneous seizure activity in hippocampal neuronal networks in culture. J Neurophysiol 73: 1706-1711, 1995.

24. Furtinger S, Pirker S, Czech T, Baumgartner C, Ransmayr G and Sperk G: Plasticity of Y1 and Y2 receptors and neuropeptide $\mathrm{Y}$ fibers in patients with temporal lobe epilepsy. J Neurosci 21: 5804-5812, 2001.

25. Sørensen G and Woldbye DP: Mice lacking neuropeptide $Y$ show increased sensitivity to cocaine. Synapse 66: 840-843, 2012.

26. Yamamoto BK and Raudensky J: The role of oxidative stress, metabolic compromise, and inflammation in neuronal injury produced by amphetamine-related drugs of abuse. J Neuroimmune Pharmacol 3: 203-217, 2008.

27. Cadet JL and Krasnova IN: Molecular bases of methamphetamine-induced neurodegeneration. Int Rev Neurobiol 88 101-119, 2009.

28. Nunes AF, Montero M, Franquinho F, Santos SD, Malva J, Zimmer J and Sousa MM: Transthyretin knockout mice display decreased susceptibility to AMPA-induced neurodegeneration. Neurochem Int 55: 454-457, 2009

29. Hoy KC, Huie JR and Grau JW: AMPA receptor mediated behavioral plasticity in the isolated rat spinal cord. Behav Brain Res 236: 319-326, 2013

30. BlairRE, Sombati S, Churn SB and Delorenzo RJ: Epileptogenesis causes an N-methyl-d-aspartate receptor/Ca2+-dependent decrease in $\mathrm{Ca}^{2+} /$ calmodulin-dependent protein kinase II activity in a hippocampal neuronal culture model of spontaneous recurrent epileptiform discharges. Eur J Pharmacol 588: 64-71, 2008.

31. Blair RE, Deshpande LS, Sombati S, Elphick MR, Martin BR and DeLorenzo RJ: Prolonged exposure to WIN55,212-2 causes downregulation of the $\mathrm{CB} 1$ receptor and the development of tolerance to its anticonvulsant effects in the hippocampal neuronal culture model of acquired epilepsy. Neuropharmacology 57 208-218, 2009

32. Gardner SM, Takamiya K, Xia J, Suh JG, Johnson R, Yu S and Huganir RL: Calcium-permeable AMPA receptor plasticity is mediated by subunit-specific interactions with PICK1 and NSF. Neuron 45: 903-915, 2005.

33. Essin K, Nistri A and Magazanik L: Evaluation of GluR2 subunit involvement in AMPA receptor function of neonatal rat hypoglossal motoneurons. Eur J Neurosci 15: 1899-1906, 2002.
34. Palmer CL, Cotton L and Henley JM: The molecular pharmacology and cell biology of alpha-amino-3-hydroxy-5-methyl-4 -isoxazolepropionic acid receptors. Pharmacol Rev 57: 253-277, 2005.

35. Montero M, Nielsen M, Rønn LC, Møller A, Noraberg J and Zimmer J: Neuroprotective effects of the AMPA antagonist PNQX in oxygen-glucose deprivation in mouse hippocampal slice cultures and global cerebral ischemia in gerbils. Brain Res 1177: 124-135, 2007.

36. Sager C, Tapken D, Kott S and Hollmann M: Functional modulation of AMPA receptors by transmembrane AMPA receptor regulatory proteins. Neuroscience 158: 45-54, 2009.

37. Colbourne F, Grooms SY, Zukin RS, Buchan AM and Bennett MV: Hypothermia rescues hippocampal CA1 neurons and attenuates down-regulation of the AMPA receptor GluR2 subunit after forebrain ischemia. Proc Natl Acad Sci USA 100: 2906-2910, 2003

38. Calderone A, Jover T, Mashiko T, Noh KM, Tanaka H, Bennett MV and Zukin RS: Late calcium EDTA rescues hippocampal CA1 neurons from global ischemia-induced death. J Neurosci 24: 9903-9913, 2004.

39. Grooms SY, Opitz T, Bennett MV and Zukin RS: Status epilepticus decreases glutamate receptor $2 \mathrm{mRNA}$ and protein expression in hippocampal pyramidal cells before neuronal death. Proc Natl Acad Sci USA 97: 3631-3636, 2000.

40. Sanchez RM, Koh S, Rio C, Wang C, Lamperti ED, Sharma D, Corfas $\mathrm{G}$ and Jensen FE: Decreased glutamate receptor 2 expression and enhanced epileptogenesis in immature rat hippocampus after perinatal hypoxia-induced seizures. J Neurosci 21: 8154-8163, 2001

41. Hanley JG and Henley JM: PICK1 is a calcium-sensor for NMDA-induced AMPA receptor trafficking. EMBO J 24: 3266-3278, 2005.

42. Zhang Y, Venkitaramani DV, Gladding CM, Zhang Y, Kurup P, Molnar E, Collingridge GL and Lombroso PJ: The tyrosine phosphatase STEP mediates AMPA receptor endocytosis after metabotropic glutamate receptor stimulation. J Neurosci 28: 10561-10566, 2008.

43. Dev KK, Nakanishi S and Henley JM: The PDZ domain of PICK1 differentially accepts protein kinase C-alpha and GluR2 as interacting ligands. J Biol Chem 279: 41393-41397, 2004.

44. Alvaro AR, Martins J, Costa AC, Fernandes E, Carvalho F, Ambrósio AF and Cavadas C: Neuropeptide $\mathrm{Y}$ protects retinal neural cells against cell death induced by ecstasy. Neuroscience 152: 97-105, 2008.

45. Baptista S, Bento AR, Gonçalves J, Bernardino L, Summavielle T, Lobo A, Fontes-Ribeiro C, Malva JO, Agasse F and Silva AP: Neuropeptide $\mathrm{Y}$ promotes neurogenesis and protection against methamphetamine-induced toxicity in mouse dentate gyrus-derived neurosphere cultures. Neuropharmacology 62: 2413-2423, 2012.

46. Jinde S, Masui A, Morinobu S, Noda A and Kato N: Differential changes in messenger RNA expressions and binding sites of neuropeptide Y Y1, Y2 and Y5 receptors in the hippocampus of an epileptic mutant rat: Noda epileptic rat. Neuroscience 115: 1035-1045, 2002

47. Woldbye DP, Nanobashvili A, Sørensen AT, Husum H, Bolwig TG, Sørensen G, Ernfors P and Kokaia M. Differential suppression of seizures via Y2 and Y5 neuropeptide Y receptors. Neurobiol Dis 20: 760-772, 2005. 